\title{
Evaluasi Pengelolaan Sediaan Farmasi dan Bahan Medis Habis Pakai Pada Puskesmas di Kabupaten Pekalongan Berdasarkan Petunjuk Teknis Standar Pelayanan kefarmasian di Puskesmas Tahun 2019
}

\author{
Erna Erviana ${ }^{1}$, Yulian Wahyu Permadi ${ }^{2 *}$, Wulan Agustin Ningrum ${ }^{3}$, Ainun \\ Muthoharoh $^{4}$ \\ ${ }^{1,2,3,4}$ Program Studi Sarjana Farmasi, Universitas Muhammadiyah Pekajangan Pekalongan, \\ Indonesia \\ *email: y.wahyu.permadi@umpp.ac.id
}

\begin{abstract}
Management of pharmaceutical preparations is a series of activities involving aspects of planning, procurement, receipt, storage, distribution, destruction and withdrawal, control and administration of drugs that are managed optimally to ensure the achievement of determination of the amount and type of pharmaceutical supplies. The purpose of this study was to evaluate the management of pharmaceutical preparations and medical consumables in health centers in Pekalongan Regency based on the Technical Instructions for Pharmaceutical Services at Puskesmas in 2019. The method used in this study was a quantitative method with descriptive quantitative analysis using simple techniques. random sampling consisting of 30 respondents from pharmacy staff in 17 health centers in Pekalongan Regency who met the inclusion criteria. The research instrument used a questionnaire with univariate analysis. The results showed that the management of pharmaceutical preparations and medical consumables (BMHP) in the planning category was very good $(100 \%)$, the procurement category was very good $(76.7 \%)$, the acceptance category was very good $(100 \%)$, the storage category was very good $(100 \%)$, very good category distribution $(90 \%)$, very good withdrawal and annihilation category $(100 \%)$, very good category control (93.3\%) and very good category administration stage (100\%). The conclusion of this study is that the implementation of the management of pharmaceutical preparations and medical consumables (BMHP) in district health centers is in accordance with the Technical Guidelines for Pharmaceutical Service Standards at Health Centers in 2019, therefore pharmaceutical staff in each health center must always improve pharmaceutical service standards in order to prosper. high public health.
\end{abstract}

Keywords: Technical Guidelines; for Pharmaceutical Services; Public health center

\begin{abstract}
Abstrak
Pengelolaan sediaan farmasi merupakan suatu rangkaian kegiatan yang menyangkut aspek perencanaan, pengadaan, penerimaan, penyimpanan, pendistribusian, pemusnahan serta penarikan, pengendalian dan administrasi obat yang dikelola secara optimal untuk menjamin tercapainya ketetapan jumlah dan jenis perbekalan farmasi. Tujuan dari penelitian ini adalah untuk mengevaluasi pengelolaan sediaan farmasi dan bahan medis habis pakai di puskesmas yang ada di Kabupaten Pekalongan berdasarkan Petunjuk Teknis Pelayanan Kefarmasian di puskesmas tahun 2019. Metode yang digunakan dalam penelitian ini adalah metode kuantitatif yang bersifat deskriptif analisis kuantitatif dengan menggunakan teknik simple rundom sampling yaitu sejumlah 30 responden tenaga kefarmasian dalam 17 puskesmas di Kabupaten Pekalongan yang memenuhi kriteria inklusi. Instrumen penelitian ini menggunakan kuesioner dengan analisis univariat. Hasil penelitian menunjukan pengelolaan sediaan farmasi dan bahan medis habis pakai (BMHP) pada perencanaan kategori sangat baik $(100 \%)$, pengadaan kategori sangat baik $(76,7 \%)$, penerimaan kategori sangat baik $(100 \%)$, penyimpanan kategori sangat baik $(100 \%)$, pendistribusian kategori sangat baik $(90 \%)$, penarikan dan pemusnahan kategori sangat baik $(100 \%)$, pengendalian kategori sangat baik $(93,3 \%)$ dan tahapan administrasi kategori sangat baik (100\%). Kesimpulan pada
\end{abstract}




\section{Prosiding Seminar Nasional Kesehatan Lembaga Penelitian dan Pengabdian Masyarakat Universitas Muhammadiyah Pekajangan Pekalongan}

penelitian ini bahwa pelaksanaan pengelolaan sediaan farmasi dan bahan medis habis pakai (BMHP) di puskesmas Kabupaten telah sesuai dengan Petunjuk Teknis Standar Pelayanan Kefarmasian di Puskesmas Tahun 2019, oleh karena itu tenaga kefarmasian di setiap puskesmas harus selalu meningkatkan standar pelayanan kefarmasian guna untuk mensejahterakan kesehatan masyarakat yang tinggi.

Kata kunci: Petunjuk; Teknis; Pelayanan; Kefarmasian; Puskesmas

\section{Pendahuluan}

Pelayanan kefarmasian di puskesmas merupakan satu kesatuan yang tidak terpisahkan dari pelaksanaan upaya kesehatan yang berperan penting dalam meningkatkan mutu pelayanan kesehatan bagi masyarakat (Departemen Kesehatan, 2016). Pengelolaan obat yaitu suatu rangkaian kegiatan yang menyangkut aspek perencanaan, pengadaan, penerimaan, penyimpanan, pendistribusian, pemusnahan dan penarikan serta pengendalian dan administrasi obat yang dikelola secara optimal untuk menjamin tercapainya ketetapan jumlah dan jenis perbekalan farmasi dengan memanfaatkan sumber-sumber yang tersedia seperti tenaga, dana, sarana dan perangkat lunak dalam upaya mencapai tujuan yang ditetapkan diberbagai tingkat unit kerja. Najoan dkk. (2019) menyatakan bahwa tujuan manajemen pengelolaan obat adalah untuk tersedianya obat setiap saat dibutuhkan baik mengenai jenis, jumlah maupun kualitas secara efisien, dengan demikian manajemen pengelolaan obat dapat dipakai sebagai proses menggerakan dan memberdayakan semua sumber daya yang potensial untuk dimanfaatkan dalam rangka mewujudkan ketersediaan obat setiap saat dibutuhkan untuk operasional yang efektif dan efisien.

Sukses atau gagalnya pengelolaan sediaan farmasi ditentukan oleh kegiatan didalam perencanaannya, misalnya dalam menentukan barang yang pengadaannya melebihi kebutuhan, maka akan mengacaukan satu siklus manajemen secara keseluruhan, akibatnya akan menimbulkan pemborosan dalam penganggaran, pembengkakan biaya pengadaan dan penyimpanan, tidak terstrukturnya obat atau barang tersebut sehingga bisa rusak atau kadaluarsa meskipun baik pemeliharaannya digudang. Pengelolaan sediaan farmasi dan bahan medis habis pakai (BMHP) merupakan kegiatan yang harus dilakukan secara disiplin dan teratur sehingga perlunya untuk dilakukan secara baik dan benar sesuai peraturan yang ada, karena suatu managemen obat jika tidak dilakukan dengan baik akan memberikan dampak yang buruk tidak hanya bagi puskesmas namun juga bagi pasien atau masyarakat.

Penelitian yang sudah dilakukan sebelumnya di Puskesmas Kabupaten Pekalongan oleh Laila Karima (2019) yaitu Evaluasi Pelaksanaan Standar Pelayanan Kefarmasian Berdasarkan Peraturan Menteri Kesehatan Republik Indonesia Nomor 74 Tahun 2016 di Puskesmas Area Kabupaten Pekalongan Tahun 2019 yaitu meneliti tentang standar pelayanan kefarmasian terhadap pelayanan farmasi klinik dengan hasil penelitian sesuai dengan literatur yang ada yaitu PERMENKS No. 74 Tahun 2016. Berdasarkan penelitian yang sudah dilakukan tersebut terdapat variaabel yang berbeda karena peneliti sebelumnya telah melakukan penelitian terkait dengan standar pelayanan dalam kegiatan pelayanan farmasi klinik, sedangkan kegiatan pengelolaan sediaan farmasi dan BMHP berdasarkan peratutan atau literatur terbri yaitu Petunjuk 


\section{Prosiding Seminar Nasional Kesehatan 2021 Lembaga Penelitian dan Pengabdian Masyarakat Universitas Muhammadiyah Pekajangan Pekalongan}

Teknis Standar Pelayanan Kefarmasian di Puskesmas Tahun 2019 belum dilakukan penelitia.

Kabupaten Pekalongan memiliki 27 puskesmas yang terdiri dari wilayah dataran tinggi dan dataran rendah. Jika dilihat dari jarak antara puskesmas dengan puskesmas lainnya saling berjauhan, begitu juga dari segi pelayanan Dinas Kesehatan dengan puskesmas ini tentunya juga akan berbeda. Kemudian banyak perbedaan lain antara puskesmas di Kabupaten Pekalongan seperti halnya tidak semua puskesmas memiliki apoteker maka bagaimana suatu siklus managemen obatnya di masing-masing puskesmas tersebut apakah sudah terlaksana dengan baik dan merata di seluruh puskesmas atau belum. Hal ini yang mendorong peneliti untuk melakukan penelitian evaluasi pengelolaan sediaan farmasi dan bahan medis habis pakai (BMHP) di puskesmas yang terletak di Kabupaten Pekalongan secara keseluruhan berdasarkan Petunjuk Teknis Standar pekayanan Kefarmasian di Puskesmas Tahun 2019.

\section{Metode}

Penelitian ini merupakan penelitian metode deskriptif analisis kuantitatif. Pengambilan sampel menggunakan probability sampling dengan teknik simple rundom sampling. Subjek dalam penelitian ini adalah tenaga kefarmasian yang bekerja di puskesmas di Kabupaten Pekalongan dan memenuhi kriteria inklusi. Instrumen penelitian yang digunakan pada penelitian ini berupa kuesioner (daftar pertanyaan).

\section{Lokasi, Waktu Penelitian}

Penelitian ini dilakukan di Ruang Farmasi puskesmas di Kabupaten Pekalongan yang dilaksanakan pada bulan April-Juni 2021 dan di lakukan di sejumlah 17 puskesmas di Kabupaten Pekalongan yang terpilih secara acak dan beradasarkan kriteria inklusi.

\section{Populasi dan Sampel Populasi}

Berdasarkan dari data Dinas Kesehatan Kabupaten Pekalongan memiliki 27 puskesmas. Dari sejumlah populasi tersebut, diambil populasi sampel puskesmas secara rundom sampling. Dalam Asari (2018), Gay Diehl Hashim menyatakan pengambilan populasi dalam penelitian ini yaitu dilakukan dengan rumus dan perhitungan sederhana yaitu dengan Rumus Slovin. Rumus Slovin digunakan dalam menentukan sampel. Peneliti dapat menentukan sendiri nilai galat pendugaan misalnya $10 \%$ atau 0,01 dari populasi. Adapun Rumus Slovin dalam penelitian ini adalah :

$$
\begin{aligned}
& \mathrm{n}=\frac{N}{N \cdot d^{2}+1} \\
& n=\frac{27}{27 \cdot 0,1^{2}+1} \\
& \mathrm{n}=\frac{27}{27 \cdot 0,01+1} \\
& \mathrm{n}=\frac{27}{1,27} \\
& \mathrm{n}=21,2
\end{aligned}
$$




\section{Prosiding Seminar Nasional Kesehatan 2021 Lembaga Penelitian dan Pengabdian Masyarakat Universitas Muhammadiyah Pekajangan Pekalongan}

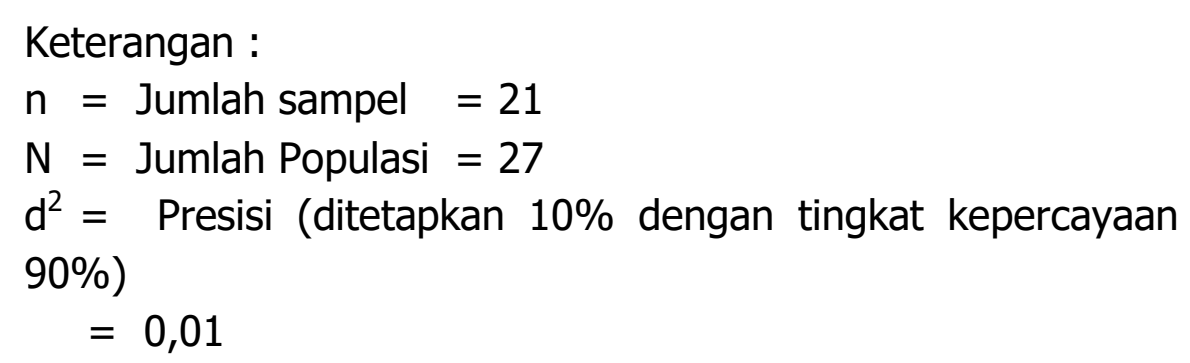

\section{Sampel}

Berdasarkan hasil rundom sampel yang telah ditentukan dengan menggunakan rumus slovin menghasilkan 21 sampel yang akan dijadikan sebagai sampel penelitian. Dari hasil sampel tersebut akan dijadikan sebagai sampel penelitian jika memenuhi kriteria inklusi.

\section{Analisis Data}

Analisis data dalam penelitian ini menggunakan progam aplikasi statistik SPSS versi 23. Data diperoleh dari kuesioner yang telah diisi oleh responden. Data yang terkumpul kemudian dianalisis menggunakan analisis univariat. Analisis ini digunakan untuk menganalisis tiap variabel dari hasil penelitian serta menganalisis variabel secara deskriptif dengan menghitung persentase. Analisis data dimulai dari mengelompokan data berdasarkan parameter-parameter, parameter utama yaitu Petunjuk Teknis Standar Pelayanan Kefarmasian di puskesmas tahun 2019, kemudian dihitung jumlah total untuk tiap alternatif jawaban. Penilaian terhadap evaluasi atau pelaksanaan pelayanan kefarmasian berdasarkan petunjuk teknis standar pelayanan kefarmasian di puskesmas tahun 2019 yang dilakukan di puskesmas se-Kabupaten Pekalongan.

Tabel 1. Skala Penilaian (Riduwan dan Akdon, 2015)

\begin{tabular}{ccc}
\hline Urutan & $\begin{array}{c}\text { Rentang } \\
\text { Capaian }\end{array}$ & $\begin{array}{c}\text { Kategori } \\
\text { Capaian }\end{array}$ \\
\hline 1 & $0 \%-20 \%$ & Sangat Kurang \\
2 & $61 \%-80 \%$ & Kurang \\
3 & $41 \%-60 \%$ & Cukup \\
4 & $61 \%-80 \%$ & Baik \\
5 & $81 \%-100 \%$ & Sangat Baik \\
\hline
\end{tabular}

\section{Hasil dan Pembahasan}

Penelitian ini dilakukan pada puskesmas di Kabupaten Pekalongan sebanyak 17 puskesmas dengan sejumlah 30 responden yang termasuk ke dalam kriteris inklusi. Penelitian dilakukan pada bulan April-Juni 2021. Sebanyak 17 puskesmas yang digunakan untuk tempat penelitian yaitu Puskesmas Kandangserang, Puskesmas Paninggaran, Puskesmas Kajen II, Puskesmas Wonopringgo, Puskesmas Kedungwuni I, Puskesmas Doro I, Puskesmas Talun, Puskesmas Buaran, Puskesmas Tirto I, Puskesmas Tirto II, Puskesmas Wonokerto I, Puskesmas Wonokerto II, Puskesmas Wiradesa, Puskesmas Siwalan, Puskesmas Sragi I, Puskesmas Sragi II dan Puskesmas Bojong I. 


\section{Prosiding Seminar Nasional Kesehatan Lembaga Penelitian dan Pengabdian Masyarakat Universitas Muhammadiyah Pekajangan Pekalongan}

\section{Hasil}

\section{Karakteristik Responden}

Karakteristik responden yang memiliki persentase tinggi yaitu menunjukkan bahwa responden berjenis kelamin prerempuan (73,5\%), berusia 26-35 Tahun $(46,7 \%)$, memiliki jabatan di puskesmas sebagai TTK (56,7\%), yang bekerja selama $>1$ tahun $(86,7 \%)$ dan yang memiliki pendidikan terakhir Diploma III Farmasi yaitu (56,7\%). Keterangan tersebut seperti yang disajikan pada tabel 2 .

Tabel 2. Data Karakteristik Responden

\begin{tabular}{|c|c|c|c|}
\hline No & Variabel & $\begin{array}{c}\text { Jumlah } \\
(\mathrm{n})\end{array}$ & $\begin{array}{c}\text { Persentase } \\
(\%)\end{array}$ \\
\hline 1. & $\begin{array}{l}\text { Jenis kelamin } \\
\text { Laki-Laki } \\
\text { Perempuan }\end{array}$ & $\begin{array}{c}8 \\
22\end{array}$ & $\begin{array}{l}26,7 \\
73,5\end{array}$ \\
\hline 2. & $\begin{array}{l}\text { Umur } \\
\text { >45 Tahun } \\
\text { 36-45 Tahun } \\
\text { 26-35 Tahun } \\
\text { <25 Tahun }\end{array}$ & $\begin{array}{c}5 \\
10 \\
14 \\
1\end{array}$ & $\begin{array}{c}16,7 \\
33,3 \\
46,7 \\
3,3\end{array}$ \\
\hline 3. & $\begin{array}{l}\text { Jabatan di Puskesmas } \\
\text { Tenaga Teknis } \\
\text { Kefarmasian (TTK) } \\
\text { Apoteker }\end{array}$ & $\begin{array}{l}17 \\
13\end{array}$ & $\begin{array}{r}56,7 \\
43,3\end{array}$ \\
\hline 4. & $\begin{array}{c}\text { Lama Bekerja } \\
\text { >1 Tahun } \\
<1 \text { Tahun }\end{array}$ & $\begin{array}{c}26 \\
4\end{array}$ & $\begin{array}{l}86,7 \\
13,3\end{array}$ \\
\hline 5. & $\begin{array}{l}\text { Pendidikan Terakhir } \\
\text { DIII Farmasi } \\
\text { Profesi Apoteker }\end{array}$ & $\begin{array}{l}17 \\
13\end{array}$ & $\begin{array}{l}56,7 \\
43,3\end{array}$ \\
\hline
\end{tabular}

\section{Pengelolaan Sediaan Farmasi dan Bahan Medis Habis Pakai (BMHP) Pada Puskesmas di Kabupaten Pekalongan}

Distribusi Frekuensi Responden berdasarkan pengelolaan sediaan farmasi dan BMHP pada puskesmas di Kabupaten Pekalongan dapat dilihat pada tabel 3.

Tabel 3. Distribusi Frekuensi Responden berdasarkan pengelolaan sediaan farmasi dan BMHP pada puskesmas di Kabupaten Pekalongan

\begin{tabular}{ccccc}
\hline No & Variabel & Kategori & $\begin{array}{c}\text { Jumlah } \\
(\mathbf{n})\end{array}$ & Persentase (\%) \\
\hline 1. & Perencanaan & Sangat Baik & 30 & 100,0 \\
\hline 2. & Pengadaan & Sangat Baik & 23 & 23,3 \\
\hline 3. & Penerimaan & Sangat Baik & 30 & 100,0 \\
\hline 4. & Penyimpanan & Sangat Baik & 30 & 100,0 \\
\hline 5. & Pendistribusian & Sangat Baik & 27 & 90,0 \\
\hline
\end{tabular}




\begin{tabular}{ccccc}
\hline No & Variabel & Kategori & $\begin{array}{c}\text { Jumlah } \\
(\mathbf{n})\end{array}$ & Persentase (\%) \\
\hline 6. & Penarikan dan Pemusnahan & Sangat Baik & 30 & 100,0 \\
\hline 7. & Pengendalian & Sangat Baik & 28 & 98,3 \\
\hline 8. & Administrasi & Sangat Baik & 30 & 100,0 \\
\hline
\end{tabular}

\section{Pembahasan}

\section{Karakteristik Responden}

Tabel 2 menunjukkan hasil jumlah responden perempuan sebanyak 22 orang lebih banyak dibandingkan dengan responden laki-laki yang hanya 8 orang. Hal ini menunjukkan bahwa responden dalam penelitian ini mayoritas adalah perempuan. Hasil tersebut dapat disimpulkan bahwa sebagian besar tenaga kefarmasian berjenis kelamin perempuan yaitu apoteker maupun TTK yang bekerja di puskesmas di Kabupaten Pekalongan kemudian juga ingin terlibat dalam emansipasi wanita yaitu salah satunya dengan cara bekerja, pernyataan ini sesuai dengan Lestari (2017).

Berdasarkan data Tabel 2 usia reponden pada penelitian ini yang memiliki jumlah responden dan persentase tertinggi dapat dilihat yaitu responden yang memiliki usia 26-35 tahun dengan jumlah persentase 46,7\%. BPS (2013) menyatakan bahwa Keragaman umur diklasifikasikan menjadi tiga kelas sesuai dengan Angkatan Kerja Nasional yaitu umur belum produktif $>25$ tahun , umur produktif 25-64 tahun dan umur tidak produktif $>64$ tahun. Usia produktif menurut Novitasari (2016) yaitu pada usia 15 sampai 64 tahun, pada usia tersebut seseorang masih semangat mempunyai semangat kerja yang tinggi. Berdasarkan hasil penelitian ini menunjukkan bahwa responden yang bekerja di puskesmas Kabupaten Pekalongan memiliki umur atau usia yang produktif sesuai dengan penjelasan teori diatas dan penelitian sebelumnya.

Tabel 2 hasil karakteristik responden jabatan yang dimiliki di puskesmas. Data tersebut menunjukkan bahwa responden yang memiliki jabatan TTK adalah sebanyak 17 responden dengan persentase $56,7 \%$ lebih banyak dibandingkan dengan jabatan sebagai Apoteker. Petunjuk Teknis Standar Pelayanan Kefarmasian (2019) dan juga Permenkes RI (2016) menyatakan dimana setiap puskesmas wajib mempunyai minimal 1 Apoteker penanggung jawab untuk melakukan penyelenggaraan pelayanan kefarmasian di puskesmas dan seorang TTK mempunyai peran yang penting juga untuk membatu seorang apoteker dalam melaksanakan pekerjaan kefarmasian di puskesmas. Berdasarkan data ini juga kurang sesuai pada Petunjuk Teknis Standar Pelayanan Kefarmasian dan Permenkes RI (2016) yang menyatakan setiap puskesmas harus memiliki 1 apoteker untuk mengendalikan standar pelayanan kefarmasian di puskesmas. Hal ini dikarenakan masih banyak puskesmas yang belum memiliki Apoteker

Hardiansah (2014) menyatakan bahwa pengalaman kerja seseorang sangat penting untuk melihat keterampilan dan pengetahuan seseorang, apabila semakin lama pengalaman kerja akan semakin pula pengetahuan yang didapatkan dan dimiliki oleh seseorang yang berkerja. Berdasarkan penelitian ini menunjukkan responden 


\section{Prosiding Seminar Nasional Kesehatan 2021 Lembaga Penelitian dan Pengabdian Masyarakat Universitas Muhammadiyah Pekajangan Pekalongan}

atau jumlah tenaga kefarmasian yang bekerja selama $>1$ tahun lebih besar dibandingkan dengan tenaga kefarmasian yang bekerja selama $<1$ tahun. Data Tabel 2 menunjukkan kesesuaian pada data penelitian ini dengan teori yang ada, kedua kategori tersebut memiliki selisih nilai yang jauh dikarenakan banyak responden yang sudah sangat lama bekerja di puskesmas tersebut bahkan terdapat beberapa responden yang bekerja selama lebih dari 10 tahun.

Berdasarkan hasil karakteristik responden pendidikan terakhir yang didapat dapat dilihat bahwa hasil yang didominasi pada lulusan terakhir adalah Diploma III Farmasi, hal ini karena disebabkan masih terdapat puskesmas yang belum ada apotekernya sehingga dari TTK tersebut yang ditugaskan untuk menanggungjawabi ruang farmasi serta mengelola pelayanan kefarmasian dipuskesmas. Selain itu TTK dari Diploma III Farmasi juga berperan secara umum sebagai asisten apoteker dari masing-masing puskesmas. Sehingga dalam setiap puskesmas perlunya seorang apoteker guna untuk bertanggungjawab dalam pelayanan kefarmasian, dalam Lestari (2017) Stuart G.W \& Laraia M.T menyatakan bahwa tingkat pendidikan individu berpengaruh terhadap kemampuan berfikir. Semakin tinggi tingkat pendidikan maka individu semakin mudah berfikir rasional dan menangkap informasi baru, sehingga semakin tinggi pendidikan seseorang semakin tinggi pula pengetahuan seseorang.

\section{Pengelolaan Sediaan Farmasi dan Bahan Medis Habis Pakai Pada Puskesmas di Kabupaten Pekalongan}

\section{a. Perencanaan}

Berdasarkan Tabel 3 menunjukkan daftar sejumlah 17 puskesmas yang terdapat di Kabupaten Pekalongan yang termasuk dalam kategori sangat baik yaitu (100\%). Kegiatan perencanaan kebutuhan obat ini juga menjadi dasar dari implementasi pengelolaan obat di puskesmas. Perencanaan kebutuhan obat yang tepat akan menghasilkan jumlah dan jenis obat yang tepat sesuai dengan kebutuhan, mencegah terjadinya kekosongan stok obat, meningkatkan penggunaan obat secara rasional dan meningkatkan efisiensi penggunaan obat (Pratiwi, dkk 2015). Dalam tahap perencanaan sediaan farmasi puskesmas selalu menggunakan formularium puskesmas maupun formulir nasional. Formularium ini dibuat oleh instalasi farmasi dari dinas kesehatan yang kemudian daftar obat tersebut disesuaikan kembali oleh puskesmas sesuai dengan kebutuhan di puskesmas.

\section{b. Pengadaan}

Berdasarkan hasil data Tabel 3 bahwa dalam tahap pengadaan pada puskesmas di Kabupaten Pekalongan dari 30 responden dalam 17 puskesmas tersebut menghasilkan data responden dengan kategori sangat baik yaitu 23 responden dengan persentase $(76,7 \%)$. Proses pengadaan obat atau sediaan farmasi dan BMHP harus dipantau oleh dinas kesehatan terhadap distributor obat atau pemasok obat ke puskesmas. Dinas kesehatan menjadi sumber utama pengadaan sediaan farmasi dan BMHP di puskesmas yang biasanya diajukan oleh seorang kepala puskesmas ke kepala dinas kesehatan diwilayahnya selain itu pengadaan obat juga bisa dilakukan secara mandiri dengan syarat harus sesuai 


\section{Prosiding Seminar Nasional Kesehatan 2021 Lembaga Penelitian dan Pengabdian Masyarakat Universitas Muhammadiyah Pekajangan Pekalongan}

dengan perundang-undangan apabila terdesak ketika kehabisan stok obat dan saat itu pula diperlukan bisa dilakukan secara mandiri. Kekosongan obat juga bisa di beli di apotek atau distributor lainnya ketika dari dinas kesehatan belum menyediakan atau menyetok obat di puskesmas puskesmas didalam wilayahnya. Berdasarkan pernyataan hasil penelitian ini puskemas di Kabupaten Pekalongan telah melakukan tahap pengadaan sediaan farmasi dan bahan medis habis pakai (BMHP) yang sesuai dengan peraturan yang ada.

\section{c. Penerimaan}

Berdasarkan hasil data Tabel 3 menunjukkan bahwa dalam tahap penerimaan pada puskesmas di Kabupaten Pekalongan yang didapatkan dari 30 responden dalam 17 puskesmas tersebut menghasilkan data dengan kategori sangat baik yaitu (100\%). Hal ini menunjukkan bahwa puskesmas di Kabupaten Pekalongan telah melakukan tahap penerimaan sesuai dengan petunjuk teknis standar pelayanan kefarmsian di puskesmas tahun 2019. Dalam kegiatan penerimaan sediaan farmasi dan bahan medis habis pakai (BMHP) apoteker maupun TTK yang menanggungjawabi gudang farmasi wajib melakukan pengecekan terhadap obat yang diserahterimakan sesuai dengan dokumen LPLPO atau sesuai permintaan sebelumnya. Pengecekan tersebut meliputi jenis, jumlah maupun tanggal kadaluwarsa hal ini dilakukan untuk menjaga ketersediaan sediaan farmasi (Kementerian Kesehatan, 2019).

\section{d. Penyimpanan}

Pada Tabel 3 menunjukkan daftar sejumlah 17 puskesmas yang terdapat di Kabupaten Pekalongan yang termasuk dalam kategori sangat baik yaitu (100\%). Tahap penyimpanan sediaan farmasi dan bahan medis habis pakai mempertimbangkan hal-hal seperti jenis ataupun bentuk sediaan farmasi, kondisi sediaan farmasi yang dipersyaratkan dalam penandaan pada kemasan seperti suhu dan kelembapan, mudah atau tidaknya meledak, kontaminasi antar sediaan apabila dicampurkan dan perhatian lebih pada sediaan dengan jenis narkotika dan psikotropika. Tata letak sediaan farmasi lebik baik disusun menurut bentuk sediaan dan alfabetis karena untuk memudahkan pada saat dilakukan penyetokan obat. Pengendalian stok obat dilakukan dengan prinsip FIFO (First In First Out) sebab umumnya obat yang datang lebih awal biasanya juga diproduksi lebih awal juga, maka akibatnya obat yang kadaluwarsa terlebih dahulu masih tersimpan pada gudang dan menyebabkan kekosongan obat (Kementerian Kesehatan, 2019).

\section{e. Pendistribusian}

Tabel 3 menunjukan daftar sejumlah 15 puskesmas yang terdapat di Kabupaten Pekalongan yang termasuk dalam kategori sangat baik yaitu dengan persentase (90,0\%). Puskesmas di Kabupaten Pekalongan yang dijadikan tempat penelitian melakukan pendistribusian pada jaringan puskesmas seperti puskesmas pembantu dan puskesmas keliling sesuai kebutuhan sub unit masing-masing dan dilakukan sesuai permintaan dari jaringan pelayanan kesehatan berdasarkan LPLPO yang diserahkan dan dimasukan ke gudang obat pada puskesmas. Pada 


\section{Prosiding Seminar Nasional Kesehatan 2021 Lembaga Penelitian dan Pengabdian Masyarakat Universitas Muhammadiyah Pekajangan Pekalongan}

pelaksanaan distribusi sediaan farmasi dan bahan medis habis pakai (BMHP) pada sub unit puskesmas tetap memiliki data input axce/ guna untuk memperhitungkan juga pengeluaran, pemasukan maupun stok obat yang ada di sub unit tersebut, hal ini dilakukan untuk meminimalisir menumpuknya obat di sub unit jaringan pelayanan sehingga menghindari banyaknya obat kadaluwarsa. Hal ini tentunya puskesmas di Kabupaten Pekalongan telah memenuhi tahapan yang berlaku dan sesuai perundangan.

\section{f. Penarikan dan Pemusnahan}

Tabel 3 menunjukkan daftar sejumlah 17 puskesmas yang terdapat di Kabupaten Pekalongan yang termasuk dalam kategori sangat baik yaitu (100\%). Pemusnahan dilakukan pada suatu produk yang tidak memenuhi persyaratan mutu, produk telah kadaluwarsa, tidak memenuhi syarat untuk dipergunakan untuk kepentingan ilmu pengetahuan atau dalam pelayanan kesehatan dan sediaan tersebut sudah benar-benar dicabut izin edarnya. Pada tahap pemusnahan sediaan farmasi yang dilakukan ditiap puskesmas, pelaksanaannya telah dijadwalkan dan dilakukan oleh Instalasi Farmasi Kabupaten, yang sebelumnya puskesmas telah mengirim formulir permohonan penarikan dan pemusnahan sediaan farmasi. Hal ini dilakukan agar pelaksanaan pemusnahan sediaan farmasi pada puskesmas di Kabupaten Pekalongan dapat dilaksanakan dengan baik oleh IFK dan dapat terkendali semaksimal mungkin.

Sedangkan pada pemusnahan resep sesuai dengan petunjuk teknis bahwa resep boleh dimusnahkan oleh puskesmas dan disaksikan tenaga kesehatan lainnya kemudian resep dapat dimusnahkan apabila dalam waktu batas simpan sudah 5 tahun, namun banyak puskesmas yang belum melakukan pemusnahan resep sehingga resep tersebut masih menumpuk pada gudang. Namun secara keseluruhan dari data tersebut berdasarkan tahap penarikan dan pemusnahan sediaan farmasi dan BMHP puskesmas di Kabupaten Pekalongan telah memenuhi standar pelayanan kefarmasian di puskesmas sesuai dengan peraturan yang berlaku.

\section{g. Pengendalian}

Berdasarkan Tabel 3 menunjukkan daftar sejumlah 16 puskesmas yang terdapat di Kabupaten Pekalongan yang termasuk dalam kategori sangat baik yaitu $(98,7 \%)$. Kegiatan pengendalian mencakup pemakaian rata-rata periode tertentu, menentukan stok optimum dimana stok sediaan farmasi diserahkan pada unit pelayanan kesehatan agar tidak terjadi kekosongan obat dan menentukan lead time (waktu tunggu) yaitu waktu yang diperlukan pasien mulai dari pemesanan sampai obat diterima (Kemenkes RI, 2010). Pada puskesmas di Kabupaten Pekalongan ini telah memenuhi standar dalam tahapan pengendalian, hal ini ditunjukkan dengan kategori yang sangat baik. Rata-rata pada setiap puskesmas petugas yang melakukan tahapan pengendalian yaitu dari tenaga kefarmasian sendiri tanpa campur tangan tenaga kesehatan lain, sehingga yang mampu mencegah ataupun mengatasi kekurangan dan kekosongan obat adalah 


\section{Prosiding Seminar Nasional Kesehatan 2021 Lembaga Penelitian dan Pengabdian Masyarakat Universitas Muhammadiyah Pekajangan Pekalongan}

tenaga kefarmasian yaitu apoteker maupun TTK itu sendiri, hal ini diharapkan pelayanan kefarmasian dapat selalu terkontrol dengan baik.

\section{h. Administrasi}

Tabel 3 menunjukkan daftar sejumlah 17 puskesmas yang terdapat di Kabupaten Pekalongan yang termasuk dalam kategori sangat baik yaitu (100\%). Kegiatan pelaporan ataupun pencatatan pada seluruh rangkaian data dalam pengelolaan sediaan farmasi dan bahan medis habis pakai di Puskesmas yang diterima, disimpan dan didistribusikan merupakan suatu hal yang dianggap sangat penting karena dapat berpengaruh pada pembuatan laporan yang dijadikan sebagai bukti terkait sediaan farmasi dan bahan medis habis pakai di Puskesmas dan administrasi harus dilakukan secara tepat dan teliti karena untuk memudahkan penelusuran kegiatan yang sudah berlalu (Depkes RI, 2010).

Sarana yang digunakan dalam pelaporan dan pencatatan yaitu kartu stok dan LPLPO (Laporan Pemakaian dan Lembar Permintaan Obat) yang berfungsi sebagai bukti pengeluaran obat di unit pengelolaan obat dan perbekalan farmasi, bukti penerimaan sediaan farmasi bukti penggunaan obat di puskesmas dan sebagai surat pesanan atau permintaan dari instansi (puskesmas) kepada Dinas Kesehatan Kabupaten/Kota. Hasil data tersebut menunjukkan hasil yang sangat baik terhadap puskesmas di Kabupaten Pekalongan dalam tahapan administrasi. Puskesmas melakukan pelaporan ini rutin setiap bulan sesuai dengan peraturan. Pencatatan, dokumentasi serta pelaporan tersebut ditujukkan kepada Dinas Kesehatan dan Instalasi Farmasi Pemerintah sebagai bukti nyata pengelolaan sediaan farmasi dan bahan medis habis pakai (BMHP) di puskesmas.

Penelitian yang dilakukan sebelumnya oleh Laela Karima (2019) di puskesmas area Kabupaten Pekalongan yaitu terkait dengan standar pelayanan kefarmasian di puskesmas dalam kegiatan farmasi klinik menurut PERMENKES 2016 menghasilkan hasil yang sangat sesuai, sedangkan penelitian ini terkait dengan standar pelayanan kefarmasian di puskesmas dalam tahap pengelolaan obat dan bahan medis habis pakai berdasarkan petunjuk teknis tahun 2019 adalah sangat sesuai dengan masing-masng persentase yang berbeda, hal ini menunjukkan bahwa puskesmas di Kabupaten Pekaongan telah melaksanakan standar pelayanan kefarmasian di puskesmas sesuai dengan peraturan yang ada.

\section{Kesimpulan}

Hasil dari bahwa hasil dari penelitian pengelolaan sediaan farmasi dan bahan medis habis pakai (BMHP) pada puskesmas di Kabupaten Pekalongan telah sesuai dengan petunjuk teknis standar pelayanan kefarmasian di puskesmas tahun 2019. Hal ini dilihat dari hasil perencanaan sediaan farmasi dan BMHP dengan kategori sangat baik dengan persentase $100 \%$, pengadaan sediaan farmasi dan BMHP memiliki kategori sangat baik sejumlah dengan persentase $76,7 \%$, penerimaan sediaan farmasi dan BMHP memiliki kategori sangat baik dengan persentase $100 \%$, penyimpanan sediaan farmasi dan BMHP memiliki kategori sangat baik dengan persentase $100 \%$, pendistribusian sediaan farmasi dan BMHP dengan kategori sangat baik memiliki persentase $90 \%$, selanjutnya pengendalian sediaan farmasi dan BMHP dengan kategori 


\section{Prosiding Seminar Nasional Kesehatan 2021 Lembaga Penelitian dan Pengabdian Masyarakat Universitas Muhammadiyah Pekajangan Pekalongan}

sangat baik dengan persentase $100 \%$, penarikan dan pemusnahan sediaan farmasi dan BMHP dengan kategori sangat baik dengan persentase $98,3 \%$ serta tahap administrasi memiliki kategori sangat baik dengan persentase $100 \%$.

\section{Referensi}

[1] Adiwijaya, W. (2018). Hubungan Lama Bekerja dan Motivasi Terhadap Kinerja Pegawai. Jurnal Bisnis Administrasi, 7(2) : 65-70.

[2] Arikunto. (2010). Prosedur Penelitian Suatu Pendekatan Praktek. Jakarta: PT. Rienika Cipta.

[3] A. Asari, B. H. "Pengembangan Ekowisata Bahari Berbasis Masyarakat di Desa Bahol Kecamatan Likupang Barat kabupaten Minahasa Utara," Jurnal IImiah Platax, Vol. 6, no. 1, pp. 29-41, 2018.

[4] Departemen Kesehatan Republik Indonesia (2016). Peraturan Menteri Kesehatan Indonesia No. 74 Tahun 2016 Tentang Standar Pelayanan Kefarmasian di Puskesmas. Jakarta: Departemen Kesehatan Republik Indonesia.

[5] Herdiansyah, R, "Pengaruh Pengalaman Kerja dan Tingkat Upah Terhadap Produktivitas Pekerja di UD Farley's Kota Mojokerto," Jurnal Ekonomi, vol. 7, no. 6, pp. 56-67, 2018.

[6] Karima, L. (2019). Evaluasi Pelaksanaan Standar Pelayanan Kefarmasian Berdasarkan Peraturan Menteri Kesehatan republik Indonesia Nomor 74 tahun 2016 di Puskesmas Area Kabupaten Pekalongan Tahun 2019. Skripsi. Fakultas Ilmu Kesehatan Universitas Muhammadiyah Pekajangan Pekalongan.

[7] Kementerian Kesehatan Republik Indonesia, 2019. Petunjuk Teknis Standar Pelayanan Kefarmasian di Puskesmas Tahun 2019. Jakarta.

[8] Najoan, G. W, "Analisis Pengelolaan Sediaan Farmasi di PuskesmaBitung Barat Kota Bitung," Jurnal Kesehatan Masyarakat, vol. 8, no. 6, pp. 335344, 2019.

[9] Pratiwi E, S. R, "Gambaran Perencanaan dan Pengadaan Obat di Puskesmas Rawat Jalan Kabupaten Rokan Hulu Tahun 2018,"Jurnal Penelitian Farmasi Indonesia, vo. 8, no. 2, pp. 85-90, 2019.

[10] Riduwan, A. (2015). Rumus dan Data Dalam Analisis Statistik. Bandung: Alfabeta

[11] Sugiyono. (2018). Metode Penelitian Kuantitatif, Kualitatif Dan R\&D. Bandung: Alfabeta. 